\title{
K.I. Osmak - an outstanding scientist in the field of agrarian economics and statistics
}

\author{
Verhunov V. \\ National Scientific Agricultural Library of the NAAS \\ 10 Heroiv Oborony Str., Kyiv, 03127, Ukraine \\ e-mail: dnsgb uaan@ukr.net \\ ORCID: 0000-0002- 5476-4845
}

Goal. To reveal the unexplored pages of an intellectual biography of the famous scientist in the field of agrarian economics and statistics, organizer of domestic agricultural experimental work, a political figure of the Ukrainian national revival, the President of the Ukrainian Main Liberation Rada K.I. Osmachko on the occasion of his 130-th anniversary. Methods. General scientific methods - analysis, synthesis, classification; historical — problemchronological, comparative-historical, biographical. Results. Generating contribution of the Ukrainian Main Liberation Rada is studied in the development of state and institutional framework of agriculture and its scientific support during the Perestroika years of statehood. Some scientific achievements of the scientist are generalized a nd evaluated in the development of the branch research, first of all, beet cooperatives, and the promotion of institutional frameworks for agriculture. Conclusions. Scientific heritage of K.I. Osmak is systematized in the following directions: social agronomy, economics, and organization of agriculture, agricultural terminology. His priority is proved in the development of the methodological foundations of beet cooperatives in Ukraine.

Key words: agriculture, agricultural research business, agricultural and beet cooperation, promotion of agricultural knowledge.

DOI: https://doi.org/10.31073/agrovisnyk202007-11

Socio-economic and cultural revival of Ukraine requires a comprehensive coverage of the main milestones and achievements of its historical progress, first of all, it concerns the leading sector of the economy - agriculture. On the way to the development of European values, the first place should include the possibility of impartial consideration of intellectual biographies of Ukrainian scientists who have glorified the nation with their selfless work. Such personalities rightly include an outstanding Ukrainian not only by birth, but also by what was done in the name of the future of our country - Kyrylo I. Osmak. The scientist went down in history, first of all, as the President of the Ukrainian Main Liberation Council (UMLC), for which he was anathema during the Soviet era. Since the mid-90s of the last century, he has been worthily returned to the pantheons of glory of Ukraine.

Contribution of K.I. Osmak in the preservation and multiplication of the national idea in the years of building the statehood of Ukraine, in particular in the formation of the UMLC, was reflected in a number of journalistic works [5, $6,9,11-13]$. In recent decades, the course of life and activities of K.I. Osmak became the subject of consideration of Ukrainian historians of science, because as it turned out, it is directly related to the introduction of effective solutions for the formation of scientific support for agriculture [7, 10]. However, it should be noted that the scientific heritage of the scientist on economics and organization of agriculture remains insufficiently researched.

The purpose of the research - on the occasion of the 130th anniversary of the birth of the famous scientist, organizer of domestic agricultural research, politician of the Ukrainian national revival K.I. Osmak to reveal the littlestudied pages of his creative biography, to systematize his scientific heritage and to generalize the most significant achievements.

Research methods. The research search is based on the principles of historical knowledge: objectivity, systemicity, continuity, complexity, multifactoriality. General scientific (analysis, synthesis, classification) and structural-functional methods are used. Stateful attention is paid to historical research methods (problemchronological, comparative-historical, retrospective, and biographical).

Research results. K.I. Osmak (Osmakov) was born on April 27 (May 9), 1890 in the town of Shyshaky, Myrhorod district, Poltava province, into a burgher family. In 1902, he graduated from the Shyshak two-grade rural (folk) school, and then until 1906 he studied at the Myrhorod province school. Then he trained at home for two years and in 1908 entered the sixth class of Poltava Alexandria Real School, where he was an active member of the student group of self-education, which he graduated in the summer of 1910. From that time, he earned for survival by private lectures institutions. In September 1910, he entered the Moscow Agricultural Institute (MAI). The difficult financial situation, as well as the need to pay for training prompted him to start working next year. For distributing illegal revolutionary literature by order of the Moscow mayor in 1911, he was administratively deported not only from Moscow but also from the province. For six months under the leadership of economist P.I. Gavsevych he worked in the Volyn province on agricultural census in the region. In the same year, he prepared the first scientific publication devoted to the work of the Volyn Provincial Agronomic Congress, in which he participated, which was published in 1913. In 1912 he worked for eight months, first as a technician and then as the head of a demonstration experimental plot on forage crops of Katerynoslav Provincial Zemstvo. The results of these studies have been published in several articles. The scientific guidance of the complex of researches was carried out by the well-known domestic agrarian scientist Professor V.V. Talanov, first of all, in comparative crops with corn culture [1]. 
In 1913, he was an agronomist-intern of the Volodymyr-Volyn Zemstvo, as well as a member of the Terminological Commission at the competition of mechanical tools for cultivating swamps in Sarny and a participant in the Volyn Provincial Agronomic Congress and the All-Russian Agricultural Congress in Kyiv. During this period, under the influence of agroeconomic ideas of the creator of domestic social agronomy - Professor O.F. Fortunatov finally formed a circle of his scientific interests, namely - public agronomy, economics and organization of agriculture.

Education in the MAI he carried out mainly in the winter between works on consolidation of knowledge. In addition, from the beginning he devotes a lot of time to student group organizations, but most of all to agronomic organizations studying Ukraine. In 1911, he organized a Terminology Commission, which, along with a similar one at the Emperor Alexander II Kyiv Polytechnic Institute, was perhaps the first to collect materials for a directory of Ukrainian agricultural terminology, mainly through expeditionary surveys in the Dnieper region. Its results are published in the magazines "Mayak", "Rada", "Rillya" (Kyiv) and "Ukrainian Life" (Moscow). He later passed this material to the Ukrainian Scientific Society, which was then finalized under his leadership at the Institute of the Ukrainian Scientific Language of the Ukrainian Academy of Sciences (now the National Academy of Sciences of Ukraine). In addition, in April 1914 he joined the Moscow Music \& Drama Club "Kobzar", created by Ukrainian students. In the same year, he worked as an intern at the Omsk Machine Research Station. In July 1915, he suspended his studies at the institute and entered for four months in the department of assistance to refugees affected by the First World War at the All-Russian Zemstvo Union, and was sent to the Southwest Front. There he first managed a food station in the town of Zbarazh (Ternopil region), and then - a food detachment in Skalat and Zbarazh bakery, which he built himself. After completing his service, he returned to study at the MAI in 1916. He actively published in Ukrainian-language editions the results of his own research on agricultural terminology. Many of them were published under pseudonyms: K. Kirdyaga, K. Shishatskyi, Iv. K-o and others. In 1915, together with O.V. Krasivskyi edits the only Ukrainian magazine for the whole empire "Warm Dew". For the nationalist manifestations described in his article "Galicia", the magazine was closed [2].

From the end of 1916, he moved to work as a pig instructor in the Kyiv province zemstvo. From this department with beginning of the Ukrainian National Democratic Revolution until April 1917, he was delegated to the Ukrainian Central Rada, while it consisted of representatives of public organizations and political parties. He took an active part in the organization of the General Secretariat, and later the Ministry of Land Affairs of the Central Rada and especially its Department of Agriculture as the head of the economic (apparatus) part of the department. He participates in the development of the agrarian policy of the Central Rada regarding the preparation of land reform through a special two-day agronomic meeting in August 1917. On his behalf, he became Secretary of the Organizing Committee for the convening of the first All-Ukrainian Agronomic and Economic Congress, which took place on October 22-26, 1917 , and became a landmark for the formation of the generating organizational foundations of branch research work and education in Ukraine. From December 3, 1917, he was the head of the publishing department of the Ministry of Land Affairs. During the Hetmanate, as a participant in the strike, he was dismissed from the position and became secretary of the Bulletin of Public Agronomy, published by the All-Ukrainian Union of Zemstvos headed by S. Petliura in Kyiv. In addition, he worked in the Central Agricultural Union ("Central"), where he headed the department of peasant beet cultivation, as well as in the magazine "Farmer" continued research on the problems of Ukrainian agricultural terminology, the results of which are published in both magazines. He was also among the 35 members of the Council of Ministers of Land Affairs from May 28 to August 24, 1918, headed by M.A. Kucharenko. On August 11,1918 , he became a member of the Spelling and Terminology Commission of the Nature Section, which consisted of 19 people founded in 1907 on the initiative of M. Hrushevskyi public scientific society of academic type - Ukrainian Scientific Society, which in 1921 merged into AUAS. According to the decision of the General Meeting of the Nature Section of October 11, 1918 K.I. Osmak was entrusted with the creation and management of its agronomic subsection. Subsequently, on the basis of the Terminology Commission of the Natural Science Section of the USS, a natural sciences department of the Institute of the Ukrainian Scientific Language was created, in which K.I. Osmak worked until 1930 inclusive. During the time of the Directory, from December 17, 1918, he again headed the publishing department of the Ministry of Land Affairs. He continues to work in this position with the establishment of Soviet power through the PCLA of the Ukrainian SSR. He went to work on August 27, 1919 to the forerunner of the modern National Academy of Agrarian Sciences of Ukraine - Agricultural Scientist Committee of Ukraine - chairman of the Promotion Section, and later, from June 1, also chairman of the Terminology Bureau. In the same year, he initiated the establishment of the Educational Institute under the Committee to promote the success of agricultural knowledge. He developed its "Charter", a program of classes that began in November 1919, and headed the institution. He works part-time at the Central, Kyiv Provincial Agricultural Union and the Farmer's Association, and deals with general issues of agricultural cooperation. He is rightly considered one of the pioneers and theorists of the development of the problem of beet cooperation in Ukraine. The sixty-page collection "Beet Cooperation", edited by K.I. Osmak in 1920, received a great resonance for its time. His other publications in 1923-1924 on this problem aroused no less interest. At the end of 1924, he prepared on 6 printed sheets the author's monograph "Sugar industry and peasant beet cultivation of the right bank of Ukraine", as well as a 92-page brochure "Seeds of sugar beet culture for the national economy" [8].

He was one of the eleven founders of the Agronomic Section founded on April 13, 1919 at the Ukrainian Scientific Society, established in 1907. In addition, together with O. Yanata, P. Gavsevych, V. Kornichyk and M. Renzkyi, he first became a member of the Provisional Council, and since January 18, 1920, the permanent Council of the Agronomic Section of the USS, which had 40 members and 10 candidates and later joined the AUAS. 
Due to family circumstances that coincided with the introduction of the NEP in the country, at the end of 1921 he moved to work in Myrhorod district, where he first considered as an agronomist-instructor, and then head of the agronomic department until March 1923. Then he returned to Kyiv again and worked as the head of the Editorial \& Publishing Bureau of ASCU. He continues to deal with issues of scientific support of agricultural cooperation by developing guidelines and methodology for its implementation. In addition, in the Kyiv Province Agrarian Union he heads the subdivision of beet cooperation. In 1923, he became a member of the Sofia Commission of the AllUkrainian Academy of Sciences, which scientifically inspected the Cathedral of St. Sophia of the XI century in terms of art, archeology and history.

At the beginning of 1925 , he became the head of the agricultural department of the Institute of the Ukrainian Scientific Language at the All-Ukrainian Academy of Sciences to complete many years of work on publishing a 20page dictionary of Ukrainian agricultural terminology. Together with O.A. Yanata in 1926, he developed a special "Instruction on the collection of agricultural names and terms" from the people. He takes an active part in public activities as a member of the Presidium of the Kyiv county branch of the Robitzemlis Union and as the executive secretary of its agricultural secretariat. In addition, he became one of the founders and developers of the "Statute" established on August 28, 1926, the Kyiv Agricultural Society, which ceased its activities on February 25 , 1927 on political charges for manifestations of nationalism [3].

He was first arrested on March 5, 1928 in Kharkiv for involvement in the "Counter-Revolutionary Organization of Right Ukrainian Nationalists in the Beet Cooperation, which was working to establish the Ukrainian Peasant Party" and sent to a camp in the Komi Autonomous Soviet Socialist Republic. After the liberation he returned to Kyiv and received an invitation from the newly established All-Ukrainian Scientific \& Research Institute of Economics and Agriculture Organization in Kharkiv (now - NSC "Institute of Agrarian Economics NAAS") to cooperate on theme "agronomic organization in the past and present" for 1928-1929. He participates in the development of his first program of scientific activities. However, he received a new accusation of pursuing a nationalist trend in compiling the Ukrainian agricultural terminology dictionary, and as a result, on September 28, 1928, a decision was made to evict him. His new place of residence is defined Kursk (Russia), where he, as an extrabudgetary staff member of the All-Ukrainian Academy of Sciences, continued to compile dictionaries of agricultural and forest terminology until the early 1930s. The next arrest in the case of the "Union for the Liberation of Ukraine" took place on March 2, 1930. In the autumn of 1933, he settled near Moscow, then moved to the village of Katine, Riazan region, where until 1938 he worked as an agronomist on a collective farm. According to the denunciation of the collective farm party secretary, he was arrested for the third time for "preparing a terrorist attack against Stalin and anti-Soviet agitation." In February 1940, in connection with a certain liberalization of the policy on Protestant manifestations, K.I. Osmak was released. In April 1940, he returned to work in Kyiv. With the beginning of the German occupation of the city, he became actively involved in the struggle against the occupiers through the propaganda work of the Ukrainian underground. At the invitation of Professor M. Velychkivskyi in October 1941, he became a member of the Ukrainian National Rada (UNR) as a representative body of the Ukrainian people, in which he headed the Department of Land Resources and the Bureau of the All-Ukrainian Society "Farmer". Despite the fact that the occupiers decided to liquidate both institutions, next month he is preparing his own version of land reform in Ukraine, which the German authorities rejected for the pro-Ukrainian bias and departure from the Soviet collective farm system. At the end of 1941, through the staff of the Department of Sugar Industry of Ukraine ("Sugar Trust"), he became acquainted with the ideology of the OUN. He created about 150 agricultural credit societies through the "Farmer" line, which he headed and which had 8 branches and 313 primary departments, which also united 65 thousand farms. The official accession to the OUN(b) took place in July 1942. At the end of September 1943, he moved to Lviv, where he prepared documents for the formation of the future Ukrainian government on behalf of the main leadership of the OUN. On June 10, 1944, the Ukrainian Main Liberation Council was established. In October 1944, at the general meeting of the UMLC, Kyrylo Osmak was elected President of the UMLC. At the end of 1944, he was arrested again and spent two years under investigation and imprisoned in Drohobych Prison. In January 1947, he was transferred to Lukianivka Prison in Kyiv, and then during 1948-1960 he was in Vladymyrets Prison, where he died on May 16, 1960 [4]. In May 1942, he wrote a declaration "Our strength is in unity", in which he called for the unification of all Ukrainian patriots for the Independent Conciliar Ukrainian State into the "Union of Ukrainian Statehood" (UUS), but the project was not implemented by the occupying power. The official accession to the OUN (b) took place in July 1942. At the end of September 1943, he moved to Lviv, where he prepared documents for the formation of the future Ukrainian government on behalf of the main leadership of the OUN. On June 10, 1944, the Ukrainian Main Liberation Council was established. In October 1944, at the general meeting of the UHVR, Kyrylo Osmak was elected President of the UGVR. At the end of 1944, he was arrested again and spent two years under investigation and imprisoned in Drohobych Prison. In January 1947, he was transferred to Lukyanivka Prison in Kyiv, and then during 1948-1960 he was in Vladimirets Prison, where he died on May 16, 1960 [4].

\section{Conclusions}

Scientific heritage of K.I. Osmak - more than 50 scientific, scientific-popular articles, as well as monographs mostly on agricultural and, above all, beet cooperation, as well as other problems of scientific support of agriculture in Ukraine. Thus, the opportunity to become a recognized scientist, expert in the agricultural sector of Ukraine and develop his own recommendations for its further effective development, including personally developed agrarian reform, is provided by close cooperation with a talented Russian agricultural economist, Professor O.F. Fortunatov, famous agricultural scientists V.V. Talanov and P.I. Gavsevich, under the influence of scientific ideas which formed the scientific worldview and priority areas of K.I. Osmak. He managed to consolidate the acquired knowledge in 
practice, working in the specialty in various sectoral research institutions of Ukraine. All this allowed him to realize himself as a leading scientist in the field of public agronomy, economics and organization of agriculture, the developer of agricultural terminology. K.I. Osmak is the founder of the methodology in the field of beet cooperation in Ukraine, as evidenced by the collection "Beet Cooperation", published by him, as well as his publications in 1923-1924 on this problem. The contribution of K.I. Osmak in the preservation and increase of the national idea in the years of statehood development in the format of the activities of UMLC, the relevant Ministry and the Agricultural Scientist Committee of Ukraine is special. He effectively engaged in promotional activities on the economy and organization of agriculture in Ukraine.

\section{References}

1. Zhadjko, V. (2012). Kyrylo Osjmak. Zapovidaju Vam Ukrajinu [Kyrylo Osmak. I bequeath to you Ukraine]. Kyiv. [In Ukrainian].

2. Zakharjak, B. (2004). Povernennja Kyryla Osjmaka [Return of Kyrylo Osmak.]. Nacija i Nation and state, 20 Dec. (n. 47), 11. [In Ukrainian].

3. Osjmak, N. K. (2010). Osjmak Kyrylo Ivanovych [Osmak Kyrylo Ivanovych]. Encyklopedija istoriji Ukrajiny [Encyclopedia of the History of Ukraine]. Kyiv: Scientific thought. (Vol. 7: MI-O, p. 696). [In Ukrainian].

4. Procj, Ja. (1996). Kyrylo Osjmak - budivnychyj Ukrajinsjkoji derzhavy [Kyrylo Osmak is a builder of the Ukrainian state]. Rural life, 7 Sep. (n. 42), 6. [In Ukrainian].

5. Shapoval, Ju. (2011). Osjmak Kyrylo Ivanovych [Osmak Kyrylo Ivanovich]. In Political encyclopedia. Kyiv: Parliamentary Publishing House. (p. 527). [In Ukrainian].

6. Kovalenko, S. D. (2011). Vnesok K. I. Osjmaka v stanovlennja ta rozghortannja dijaljnosti Populjaryzacijnoji sekciji Siljsjkoghospodarsjkogho naukovogho komitetu Ukrajiny (1919-1923) [Contribution of K. I. Osmak in the formation and development of the Popularization Section of the Agricultural Scientific Committee of Ukraine (19191923)]. Aktualjni pytannja istoriji nauky i tekhniky: mater. 10-ji Vseukr. nauk. konf., m. Kyjiv, 6-8 zhovtnja 2011 r. [Current issues in the history of science and technique: Proceedings of the 10th All-Ukrainian Scientific Conference, Kyiv, October 6-8, 2011]. Kyiv, 2011. (pp. 282-284). [In Ukrainian].

7. Pidghajna, T. (2014). K. Osjmak (1890-1960) - teoretyk rozrobky problemy burjakovoji kooperaciji v Ukrajini pershoji polovyny 20-kh rokiv XX st. [K. Osmak (1890-1960) - theorist of the development of the problem of beet cooperation in Ukraine in the first half of the 20st of the 20 century]. Naukovi zapysky Ternopiljsjkogho nacionaljnogho pedaghoghichnogho universytetu imeni Volodymyra Ghnatjuka [Scientific notes of Ternopil National Pedagogical University named after Volodymyr Hnatyuk]. Ternopil. (Vol. 1, Ch. 3, pp. 119-122). [In Ukrainian].

8. Verhunov, V. A. (2013). Aghroekonomichna spadshhyna ostannjogho prezydenta Ukrajinsjkoji gholovnoji vyzvoljnoji rady Kyryla Osjmaka: povernennja iz zabuttja [The agro-economic heritage of the last president of the Ukrainian Main Liberation Council, Kyrylo Osmak: a return from oblivion]. Evening Poltava, 10 Apr. [n. 15], 5-8. [In Ukrainian].

9. Verhunov, V.A. (2012). K. I. Osjmak - derzhavnyj dijach ta odyn z orghanizatoriv i populjaryzatoriv naukovogho zabezpechennja siljsjkogho ghospodarstva Ukrajiny u 1911-1928 rr. [K. I. Osmak - state figure and one of the organizers and promoters of scientific support of agriculture in Ukraine in 1911-1928]. Istorychni zapysky: zb. nauk. pr. [Historical notes: collection of scientific works]. (Vol. 36, pp. 31-48). [In Ukrainian].

10. Verhunov, V., \& Pidghajna, T. (2014). Osjmak Kyrylo Ivanovych (1890-1960): biobiblioghr. pokazhch. nauk. pr. za 1911-1926 rr. [Osmak Kyrylo Ivanovych (1890-1960): bibliographic index of scientific works for 1911-1926]. Kyiv: FOP Korzun D. Ju. [In Ukrainian].

11. Verhunov, V. A. (2014). K. I. Osjmak (Osjmakov) (1890-1960) - ukrajinsjkyj uchenyj-aghrarnyj ekonomist, derzhavnyj ta politychnyj dijach [K. I. Osmak (Osmakov) (1890-1960) - Ukrainian scientist-agrarian economist, state figure and politician]. Kyiv: FOP Korzun D. Ju. [In Ukrainian].

12. Verhunov, V. A. (2014). Kyrylo Osjmak (Osjmakov): (do 125-richchja vid dnja narodzhennja). Ukrajinsjkyj uchenyj - aghrarnyj ekonomist, derzhavnyj i politychnyj dijach [Kyrylo Osmak (Osmakov): (to the 125th anniversary of his birth). Ukrainian scientist - agricultural economist, state figure and politician]. Outlook, 5(49), pp. 25-33. [In Ukrainian].

13. Topchij, A. (2004). Prezydent UGhVR Kyrylo Osjmak [President of the UMLC Kyrylo Osmak]. Nation and state, 15-21 June. (n. 22), 8. [In Ukrainian]. 